\title{
Wood vinegar seed priming improves yield and suppresses weeds in dryland direct-seeding rice under rainfed production
}

\author{
Bubpha Simma $^{1}$ - Anan Polthanee ${ }^{1} \cdot$ A. Susana Goggi ${ }^{2} \cdot$ Boonmee Siri $^{1}$. \\ Arunee Promkhambut ${ }^{1}$. Petrutza C. Caragea ${ }^{3}$
}

Accepted: 9 October 2017 / Published online: 30 October 2017

(C) INRA and Springer-Verlag France SAS 2017

\begin{abstract}
A declining farm labor force and increasing water scarcity worldwide are forcing rice farmers to adopt directseeding rice production. Under this production system, speed of germination, field emergence, and crop yield depend prominently on rice seed vigor. We hypothesized that seed priming can enhance rice seed vigor and agronomic performance. The objective of this study was to evaluate the effect of $\mathrm{GA}_{3}$ and wood vinegar seed priming on seed vigor, seedling performance, and grain yield in farmer's fields. The experimental design was a split-split plot with four replications and planted in Thailand between April to December 2013 and 2014. Two rice cultivars (KDML 105 and RD6) were main plots; two planting methods (broadcast and row) were sub-plots, and three seed priming treatments $\left(\mathrm{GA}_{3}\right.$, wood vinegar, and untreated control) were sub-sub-plots. Seed priming enhanced speed of germination and final germination percentage under both laboratory and field condition. However, soil moisture availability during flowering and seed formation significantly affected agronomic performance. Wood vinegar-primed seeds had greater shoot growth and plant population at maturity, while $\mathrm{GA}_{3}$-primed seed had more rapid germination. Yieldrelated agronomic performance characteristics of tillers plant $^{-1}$ and yield in ton $\mathrm{ha}^{-1}$ were significantly higher for primed seed, and weed biomass was significantly reduced in
\end{abstract}

A. Susana Goggi

susana@iastate.edu

1 Department of Plant Science and Agricultural Resources, Faculty of Agriculture, Khon Kaen University, Khon Kaen, Thailand

2 Department of Agronomy/Seed Science Center, 195C Seed Science, Iowa State University, Ames, IA, USA

3 Department of Statistics, 1121C Snedecor, Iowa State University, Ames, IA, USA
2013. Here, we show for the first time that wood vinegar is a sustainable alternative to chemicals for seed priming. Also, when water is available during flowering and seed development, wood vinegar priming increases grain yield and reduces weed pressure.

Keywords Seed priming $\cdot$ Seed soaking $\cdot$ Dry-direct seeding rice $\cdot$ Oryza sativa $\mathrm{L}$. · Weed competition

\section{Introduction}

Rice production requires a steady and abundant water supply. Water resources worldwide are becoming scarce due to fluctuations in rainfall patterns. Consequently, farmers in Asia are replacing conventional transplanting rice (C-TPR) with directseeding rice (DSR) (Pandey and Velasco 2002). DSR requires 35-40\% less water and less manual labor than C-TPR, which also alleviates concerns for an ever-scarce labor force (Kumar and Ladha 2011) and ever-increasing labor cost (Pandey and Velasco 2002). Today, 23\% of the total rice area in Asia is under DSR production (Rao et al. 2007). There are three DSR methods currently in use; water direct-seeding or Water-DSR, where pre-germinated seeds are sown into standing water; wet direct-seeding or Wet-DSR, where pre-germinated seeds sown into saturated soil; and dry direct-seeding or Dry-DSR, where dry seeds are sown into moist soil. In all these methods, seeds are sown directly into the soil without transplanting (Rao et al. 2007). However, water savings are greatest for Dry-DSR (Kumar and Ladha 2011), making Dry-DSR the best sustainable practice for rainfed rice production.

Dry-DSR is traditionally used in rainfed upland, lowland, and flood-prone areas of Asia (Rao et al. 2007). However, low soil moisture at planting can lead to low plant population and high weed infestation (Du and Tuong 2002) (Fig. 1). Rice 
Fig. 1 Drought stress negatively affects rice germination and seedling establishment leading to poor plant population densities (a) and high weed infestation (b) in dryland dry-direct seeded farmer's rice fields in Thailand

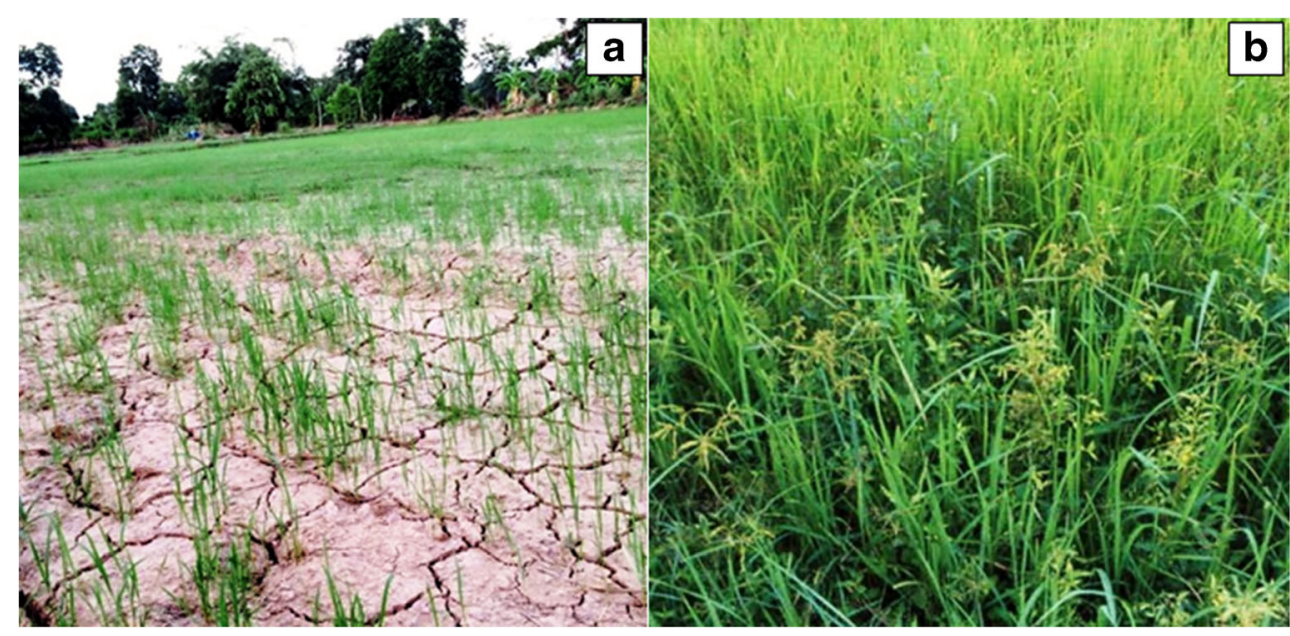

farmers use herbicides and increase seeding rates to mitigate weed problem and improve grain yield. However, increasing seeding rates reduce weed pressure and increase grain yields in broadcast-planted fields (Anwar et al. 2011) but not in rowplanted rice fields (Ghansham and Surjit 2008), where the use of herbicide was necessary to increase grain yield. The indiscriminate use of herbicides may result in human health and environmental hazards (Phuong et al. 2005) and higher production costs (Pandey and Velasco 2002). Hand weeding could be used for weed management but an estimated 150 to 200 labor day ${ }^{-1} \mathrm{ha}^{-1}$ are required to control weeds (Roder 2001), which is time-consuming and increases production cost.

"Seed priming" is a seed enhancement technique where seeds are partially hydrated until the germination process begins, but radical emergence does not occur (Giri and Schilinger 2003). This technique reduces the time to seed emergence and improves seed germination and crop stand in many crops (Ashraf and Foolad 2005). Hydro-priming rice seeds with gibberellic acid $\left(\mathrm{GA}_{3}\right)$ or ethylene $(\mathrm{ET})$ increased seedling growth (Watanabe et al. 2007) in the laboratory. Seed priming improved allometric traits, grain yield, and harvest index in rice (Farooq et al. 2008). Osmohardening with $\mathrm{CaCl}_{2}$ improved stand establishment, agronomic performance, and yield in direct-seeded, row-drilled rice under weekly irrigation (Rehman et al. 2011).

The cultivars Khao Dawk Mali 105 (KDML 105) and Rice Devision6 (RD6) are aromatic rice cultivars grown predominantly in northern and northeastern in Thailand (Sarkarung et al. 2000). KDML 105 is cultivated for local consumption and for export because of its non-glutinous aromatic quality. RD6 is a glutinous aromatic rice cultivar derived through mutation breeding from KDML 105. These cultivars have very similar agronomic characteristics, differing only in their cooking quality. They are both classified as moderately drought tolerant (Cha-um et al. 2010) and have little or no seed dormancy.

Wood vinegar or pyroligneous acid is a liquid by-product of charcoal burning. It is commonly used in Asia to control insects (Wititsiri 2011) and plant-pathogenic fungi and bacteria (Chalermsan and Peerapan 2009). Foliar applications of wood vinegar also improved yield components in rice (Berahim et al. 2014). To our knowledge, wood vinegar has not been used to prime rice seed under Dry-DSR condition. The objective of this study was to investigate the effect of seed priming with $\mathrm{GA}_{3}$ and wood vinegar on speed of germination, seed germination, seedling stand and plant population density, weed suppression, and grain yield of two rice cultivars under row and broadcast planting methods grown under Dry-DSR, dryland rice production.

\section{Materials and methods}

\subsection{Time, location, experimental design, and materials}

This study was conducted on a farmer's field in the village of Koksri, Muang district, in Khon Kaen province, Thailand (latitude $14^{\circ} 26^{\prime}$ North and longitude $102^{\circ} 48^{\prime}$ East) at an altitude of $190 \mathrm{~m}$ above sea level. The experiment was repeated for 2 years during April to December 2013 and 2014.

The experimental design was a split-split plot with four replications. Two rice cultivars (KDML 105 and RD 6) were assigned as main plots. Two planting methods (broadcast and row-drilling) were assigned as sub-plots, and three seed priming methods were assigned as sub-sub-plots. The priming treatments used were as follows: $\mathrm{GA}_{3}$ priming (Watanabe et al. 2007), wood vinegar priming, and a dry-seeded control. All cultivars were obtained from Agriculture Cooperative, Khon Kaen province, Thailand. 


\subsection{Seed moisture content and treatments}

Initial, after priming, and after re-drying seed moisture content was determined in three seed samples per cultivar and priming treatment according to Ellis et al. (1985). In this experiment, initial seed moisture content was 10.69 and $11.21 \%$ in RD6 and KDML105 rice cultivars, respectively. After priming, seed moisture content ranged from 30.32 to $31.73 \%$. Seeds were then re-dried from 11.0 to $11.65 \%$.

All seeds were surface-sterilized by using $5 \%(v / v)$ sodium hypochlorite solution before starting the experiments. Surface-sterilized seeds were rinsed three times with distilled water and dried with tissue papers (Farooq et al. 2008). The ratio between seed weight ( $250 \mathrm{~g}$ seeds) to sterilizing solution $\left(\mathrm{g} \mathrm{mL}^{-1}\right)$ was 1:5 (Rehman et al. 2011). The seeds of the $\mathrm{GA}_{3}$ priming treatment were soaked with $100 \mathrm{ppm}$ of $\mathrm{GA}_{3}$ (The Institute of Biotechnology and Genetic Engineering, Chulalongkorn University) for $48 \mathrm{~h}$ (Watanabe et al. 2007). The seeds of the wood vinegar priming treatment (TPI Polene Bio-organic Co., Ltd., Bangkok, Thailand) were soaked with 1:300 $(v / v)$ (wood vinegar, distilled water) for $48 \mathrm{~h}$ (Sungwal, personal communication). All priming treatments were applied at $25 \pm 3{ }^{\circ} \mathrm{C}$ of room temperature. Then, seeds were rinsed at three times with distilled water to remove remnant priming solutions. Seeds were re-dried using an Air-dryer SKK 09 (Ceres International Co., Bangkok, Thailand) for $10 \mathrm{~h}$ or until equilibrium seed moisture content at $30^{\circ} \mathrm{C}$ was reached. Seeds were cooled and sealed in polythene bags and stored in refrigerator at $15{ }^{\circ} \mathrm{C}, 50 \%$ relative humidity until the experiments were conducted within 30 days.

\subsection{Land preparation and crop management}

Soil was tilled three times and fields were divided into $4 \times 4 \mathrm{~m}^{2}$ plots. The plots were delimited by $50 \mathrm{~cm}$ wide and $60 \mathrm{~cm}$ tall ridges built from topsoil. Topsoil within the plots was leveled to promote even seed germination and crop growth. Fertilizer $\left[\mathrm{N}\left(46 \% \mathrm{~N}_{2}\right), \mathrm{P}\left(18 \% \mathrm{P}_{2} \mathrm{O}_{5}\right)\right.$, and $\mathrm{K}(50 \%$ $\left.\mathrm{K}_{2} \mathrm{O}\right)$ ] was applied before sowing at a rate of $156 \mathrm{~kg} \mathrm{ha}^{-1}$ $\left(250 \mathrm{~g} \mathrm{plot}^{-1}\right)$. Seeds were sown on 8 July 2013 and 12 July 2014 at a rate of $200 \mathrm{~g} \mathrm{plot}^{-1}\left(125 \mathrm{~kg} \mathrm{ha}^{-1}\right)$. Seeds within plots were either planted in rows or broadcasted. In rowplanted plots, $10 \mathrm{~g}$ of seeds were drilled in rows $20 \mathrm{~cm}$ apart (20 rows plot ${ }^{-1}$ ), and in broadcasted plots, $200 \mathrm{~g}$ seeds per plot were broadcasted evenly throughout the plot. Seeds were covered with $2.5 \mathrm{~cm}$ deep soil to prevent predation (Kumar and Ladha 2011). A second $63 \mathrm{~kg} \mathrm{ha}^{-1} \mathrm{~N}$ fertilizer application was completed at the developmental stage of panicle initiation. A carbendazim (N-(2-benzimidazole, 50\% WP) preventive fungicide treatment was applied every 7 days at rate of $20 \mathrm{~g}$ per $20 \mathrm{~L}$ of water to prevent rice blast and at heading to prevent neck blast. Weeds were controlled by hand weeding at 20 days after sowing (DAS) and 40 DAS.
2.4 Climatic conditions, soil properties, and soil water status

Daily rainfall $(\mathrm{mm})$, relative humidity $(\%)$, and maximum and minimum air temperature $\left({ }^{\circ} \mathrm{C}\right)$ from planting to harvest were obtained from the Meteorological Department of Khon Kaen province, Thailand.

Soil was from Maha Sarakham series, and soil analysis was performed on four topsoil samples collected from the experimental site every year before planting, at variable depths between 0 and $30 \mathrm{~cm}$. Samples were mixed, and composite samples were air-dried, ground, and sieved through a $2-\mathrm{mm}$ sieve. The soil samples were analyzed in 2013 and 2014 using the following methodology: physical properties were determined by the Pipette method. Chemical analysis was obtained for total N (Kjeldahl method), available P (Bray II and molybdenum blue), exchangeable $\mathrm{K}$ ( $1 \mathrm{~N} \mathrm{NH}_{4} \mathrm{OAc} \mathrm{pH} 7$ and Flame photometry), organic matter (Walkley and Black 1934), and soil pH (Benchtop pH, Sper Scientific, AZ, USA).

Soil moisture was measured before planting and harvesting using gravimetric analysis. Soil moistures were randomly measured in four areas of the plot at $0-15,15-30,30-45$, and $45-60 \mathrm{~cm}$ depths. Wet soil (WW) was weighted and then dried at $105{ }^{\circ} \mathrm{C}$ for $72 \mathrm{~h}$ or until constant dry weight. The percentage of soil moisture by weight was calculated using the formula:

Moisture $(\%)=[(\mathrm{WW}-\mathrm{DW}) / \mathrm{DW}] \times 100$

The ground water level was measured every 2 weeks by using an observation well. The inside of the well was lined with perforated Polypipe tube $100 \mathrm{~cm}$ long and $4 \mathrm{~cm}$ in diameter. A series of holes $10 \mathrm{~mm}$ in size were drilled along the length of the tube at $10 \mathrm{~cm}$ intervals and separated by $4.2 \mathrm{~cm}$ along the perimeter of the tube ( 27 holes per tube). Tubes were buried $90 \mathrm{~cm}$ deep, leaving $10 \mathrm{~cm}$ above the soil surface. A plastic cover was placed on top of each tube to protect the central shaft from rainfall.

\subsection{Seedling germination and plant population density}

Seed germination initiation (TG) or radicle protrusion, and final germination percentage (FGP) were recorded in the laboratory and field. Under laboratory conditions, seed germination tests were conducted using the Between Paper Method (ISTA 2004). Four replications of 50 seeds per treatment were placed on top of two moistened paper towels and covered with a third paper towel, then rolled loosely into a tube. Paper towels were moistened daily with $2 \mathrm{~mL}$ day $^{-1}$ of distilled water for 10 days. The tests were placed inside the germinators (SNIJDERS, Economic deluxe, Netherlands) at $25{ }^{\circ} \mathrm{C}$ of temperature, $12 \mathrm{~h} \mathrm{day}^{-1}$ of photoperiod, and $40 \mathrm{~J} \mathrm{~m}^{-2} \mathrm{~s}^{-1}$ of light intensity throughout the test. 
Seedling emergence data under field conditions were recorded for each plot in a $30 \times 30$-cm sampling area. The seeds were visually evaluated daily, and days from planting to germination were recorded.

First and FGP were recorded at 7 and 14 DAS in both laboratory and field conditions. Percentage of normal seedlings was determined according to the Handbook of International Seed Testing Association (ISTA 2004). First and final counts were computed using the following formula:

FGP $(\%)=($ Number of normal seedling $\times 100) /$ total number of seed

\subsection{Shoot biomass and crop growth rate}

Shoot biomass was determined by cutting the aerial portion of all seedlings within a $50 \times 50-\mathrm{cm}$ area of each plot. Seedlings were counted and dried in an air oven (Memmert Universal Oven UF 750 , Memmert Gmblt+Co.KG, Germany) at $80{ }^{\circ} \mathrm{C}$ for $48 \mathrm{~h}$ or until constant weight. Dry seedlings were weighed and shoot biomass recorded in mg plant ${ }^{-1}$ (SDW). Crop growth rate (CGR) was calculated using the following formula:

\section{$\mathrm{CGR}=(\mathrm{SDW}$ at final count $-\mathrm{SDW}$ at first count $)$}

/(final count day no.-first count day no.)

where SDW = seedling dry weight $\left(\mathrm{mg}\right.$ plant $\left.^{-1}\right)$.

\subsection{Plant population and weed competition}

Plant population density per square meter was counted at $1 \times 1 \mathrm{~m}^{2}$ sampling area in each plot at harvest.

Weed biomass data were obtained from a $1 \times 1$-m sampling area at 20,40, and 140 DAS. Weeds were cut above ground, cleaned and dried in an air oven (Memmert Universal Oven UF 750 , Memmert Gmblt+Co.KG, Germany) at $80{ }^{\circ} \mathrm{C}$ for $48 \mathrm{~h}$ or until constant dry weight. Dry weed biomass were weighted and recorded as $\mathrm{g} \mathrm{m}^{-2}$.

\subsection{Yield and yield components}

Grain yield and yield components were recorded at harvest. Average number of tillers plant ${ }^{-1}$ was counted in five randomly selected plants plot $^{-1}$. Plant population $\mathrm{m}^{-2}$ and average percentage of fertile and non-fertile panicles $\mathrm{m}^{-2}$ were recorded from a $1 \times 1-\mathrm{m}^{2}$ area selected at random within each plot. Total number of seed panicle ${ }^{-1}$, seed weight (fertile florets) panicle $^{-1}$, weight of empty (non-fertile) florets panicle ${ }^{-1}$, total seed weight panicle ${ }^{-1}, 1000$ seed weight, and percentage of fertile and non-fertile florets were determined from ten randomly selected plants. Grain yield was recorded from a
$3 \times 3-\mathrm{m}^{2}$ harvest area per plot; the number of plants was counted, and the average grain yield per plant was calculated in $g$ plant $^{-1}$. Grain was cleaned and yield was calculated in ton $\mathrm{ha}^{-1}$ at $14 \%$ seed moisture. Harvest index (HI) was calculated as a ratio of grain yield per biological yield (above ground biomass + grain yield) by using the following formulae:

$\mathrm{HI}(\%)=($ Grain yield $/$ Biological yield $) \times 100$

\subsection{Data analysis}

As stated previously, the experiment was a split-split plot design and replicated four times. The data were analyzed as a split-split plot design, where "Replication" was the blocking factor, and the three treatment factors were as follows: whole plots (rice cultivars, randomized to large plots in the field), split-plot factor (planting method, randomized to small plots in the field), and split-split plot factor (seed priming treatments, randomized to smaller plots in the field: within small plots, within large plots in the field). Thus, the treatment structure is a full factorial in the three treatment factors and the blocks. The analysis was performed separately for each of the independent variables. The statistical model employed was a full factorial model for the three treatments, treated as fixed effects, and included two random terms, replication $\times$ cultivar and replication $\times$ cultivar $\times$ planting method. The analysis of variance and mean comparisons were performed using JMP Pro version 12.0.1 (SAS Institute, Cary, NC). The treatment means were analyzed and corrected for multiple comparisons using the Tukey-Kramer adjustment and considered significant at a 0.05 level of probability. We verified that data do not violate the assumption of constant variance and normality by constructing residual plots and quantile-quantile plots of residuals.

\section{Results and discussion}

\subsection{Climatic conditions and soil water status}

The soil texture was sandy both years. The physical properties included 84.8 and $81.7 \%$ sand, 12.9 and $10.5 \%$ silt, and 2.2 and $2.7 \%$ clay, respectively, in 2013 and 2014. Chemical analysis showed soils had 0.03 and $0.02 \mathrm{mg} \mathrm{kg}^{-1} \mathrm{~N}, 29.7$ and $27.4 \mathrm{mg} \mathrm{kg}^{-1}$ available $\mathrm{P}$, and 77.8 and $78.2 \mathrm{mg} \mathrm{kg}^{-1}$ exchangeable K, respectively, in 2013 and 2014. Organic matter was 0.7 and 0.8 , and soil $\mathrm{pH}$ of 6.0 and 5.8, respectively, in 2013 and 2014.

The relative humidity during the growing season ranged from 62 to $96 \%$ and from 59 to $93 \%$, and total rainfall were 647 and $628 \mathrm{~mm}$ in 2013 and 2014, 
respectively. Soil moisture content before planting was 8.32 and $11.99 \%$ in 2013 and 2014, respectively. The total rainfall and rainfall distribution, and consequently water deficit, were different in both years. From seed germination to tillering (0-60 DAS), the rainfall was 177.8 and $184.4 \mathrm{~mm}$ in 2013 and 2014, respectively. However, the rain distribution in 2013 was irregular, which produced a water deficit between 42 and 60 DAS. The ground water level was deeper during this period compared with 2014 (Fig. 2), but shallower between 70 DAS until harvest in 2013. This water deficit created very different growing conditions both years, so data were analyzed by year. From flowering to maturity (90-120 DAS), total amount of rainfall was similar (1.4 and $7.1 \mathrm{~mm}$ in 2013 and 2014, respectively), and soil moisture content at harvest was 8.31 and $8.23 \%$ in 2013 and 2014, respectively.

Maximum temperature (T-max) and minimum temperature (T-min) were similar both years (data not shown). Temperatures ranged from 19.6 to $36.3{ }^{\circ} \mathrm{C}$ and from 18 to $36{ }^{\circ} \mathrm{C}$ in 2013 and 2014 , respectively, and the averages were 27.7 and $28.0{ }^{\circ} \mathrm{C}$ in 2013 and 2014 , respectively. These temperatures were ideal for rice seed germination and seedling growth (Moldenhauer et al. 2013).

\subsection{Germination, seedling vigor, and plant population density}

The FGP of $\mathrm{GA}_{3}$-primed seed (99\%) was significantly greater than that of wood vinegar-primed seeds $(95 \%)$ under laboratory conditions, but not different from control seed (98\%). Seed priming entails raising seed moisture content to phase II of water imbibition, and allowing this phase of active seed metabolism to lengthen, while preventing the onset of germination (McDonald 1998). During this phase, macromolecules are hydrolyzed, and new synthetized organelles accumulate in the embryo in preparation for germination. These primed seed remain at a higher and more uniform metabolic "activation" after dehydration and germinated more quickly than the untreated control (Tian et al. 2014; Basra et al. 2005). However, in our experiments, wood vinegar reduced FGP under laboratory conditions for both rice cultivars (KDML 105 and RD6).

The year effect was statistically significant in the field experiments, so data were analyzed separately for each year. The three-way interactions between variety, planting method, and priming treatment were not significant, but many of the twoway interactions were. The two-way interactions for four agronomic parameters [DAS, number of plants $\mathrm{m}^{-1}$, number of tillers plant ${ }^{-1}$, and number of panicles plant $\left.{ }^{-1}\right]$ included priming treatment for at least 1 year (data not shown) indicated a strong year effect. Overall, rice treated with wood vinegar germinated significantly faster and had greater germination percentage than the untreated control in the field experiments, but the FGP values were not different than $\mathrm{GA}_{3}$. Wood vinegar is rich in butenolide (butenolide 3-methyl-2Hfuro[2,3c]pyran-2-one), a compound derived from combustion of cellulose and considered the main contributor to promoting germination in seed (Flematti et al. 2004).

$\mathrm{GA}_{3}$-primed seeds germinated significantly earlier (fewer DAS) in the field than seed primed with wood vinegar and the untreated control (Fig. 3) both years. In 2014, the interaction between planting method and priming treatment was significant, but still $\mathrm{GA}_{3}$ emerged sooner regardless of planting method. $\mathrm{GA}_{3}$ and wood vinegar-primed seeds also had significantly greater FGP, but the effect of these seed priming treatments on emergence (stand establishment), expressed as plants $\mathrm{m}^{-2}$, was inconsistent. In 2013, seed priming treatments
Fig. 2 Ground water depth from soil surface $(\mathrm{cm})$ during the 2013 (a dashed line) and 2014 (a solid line) growing seasons under dryland Dry-DSR rice production

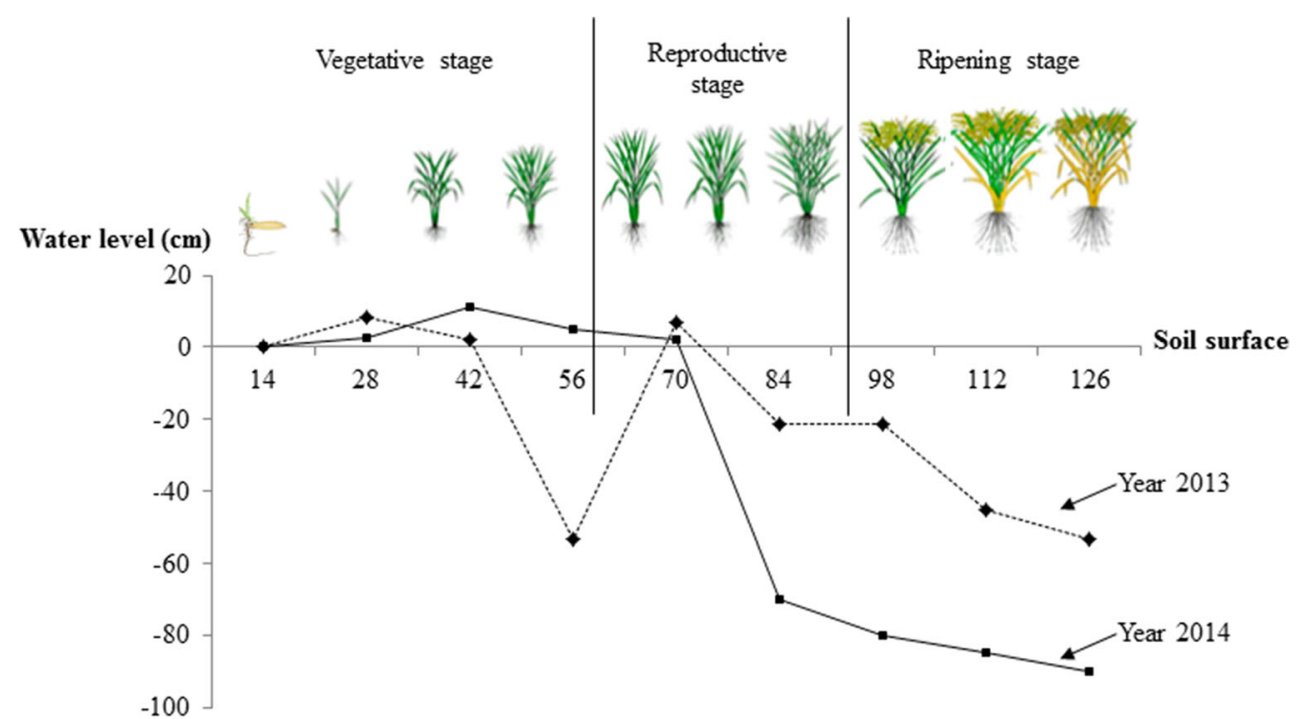

Days after sowing (days) 
had no effect on emergence for seeds planted in rows but significantly affected emergence when seed was broadcastplanted. However, emergence of wood vinegar-primed seed was not significantly different from the control. Other authors have found greater FGP in seeds primed with $\mathrm{GA}_{3}$. GA is known to regulate many growth and developmental processes in plants (Hedden and Phillips 2000), including seed germination. $\mathrm{GA}_{3}$ is produced by the embryo and released into the endosperm during seed rehydration and germination. $\mathrm{GA}_{3}$ also activates cells from the aleurone layer to synthesize and release $\alpha$-amylase and other hydrolases into the endosperm. These enzymes hydrolyze starch and other storage nutrients in the endosperm, which are mobilized to the growing embryo (Jacobson et al. 1995). In our study, wood vinegar reduced DAS in the field and increased FGP, but the effect was not significantly different than $\mathrm{GA}_{3}$.

The effect of priming treatments on other early agronomic performance parameters was inconsistent. Shoot biomass and daily crop growth rate (CGR) of plants from primed seed was significantly greater only in 1 year (data not shown). Overall, wood vinegar enhanced plant growth and could be used in rice production, but its effect was not different from $\mathrm{GA}_{3}$. Guan et al. (2014) also found that $\mathrm{GA}_{3}$ seed priming can improve shoot and root biomass in sorghum seeds.

\subsection{Effects on weed suppression}

The effect of priming treatment on weed biomass at 20 and 40 days after planting varied for different rice cultivars and planting methods. Significant two-way and three-way interactions among cultivars, planting methods, and seed priming $(\mathrm{C}$, $\mathrm{P}$, and $\mathrm{S}$ ) were found for weed biomass at 20 and 40 DAS but not for weed biomass at 140 DAS in 2013 (data not shown). Overall, weed biomass was significantly reduced in plots planted with $\mathrm{GA}_{3}$ and wood vinegar-primed seeds for both cultivars at 20 and 40 DAS (data not shown). These weed biomass values were not significantly different between plots planted with $\mathrm{GA}_{3}$ or wood vinegar-primed seed. For example,
Fig. 3 Seedling emergence in DAS $(\mathbf{a}, \mathbf{b})$, final germination in percentage $(\mathbf{c}, \mathbf{d})$, and emergence in plants $\mathrm{m}^{-2}(\mathbf{e}, \mathbf{f})$ in farmer's field plots planted with primed seed in 2013 (left column) and 2014 (right column). Priming treatments were hydro-priming with $\mathrm{GA}_{3}$, hydro-priming with wood vinegar, and untreated control. Significant planting effects (broadcast vs. row planting) were observed for DAS in 2014 and emergence in 2013
2013

a No. days after sowing

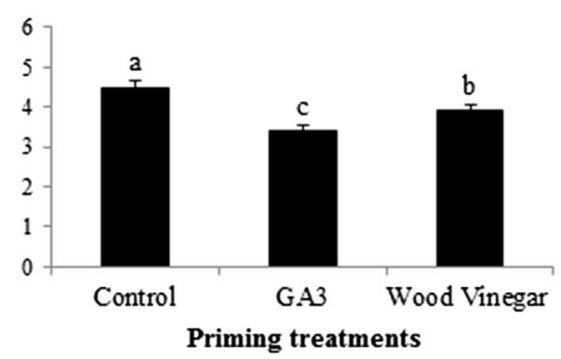

C Germination (\%)

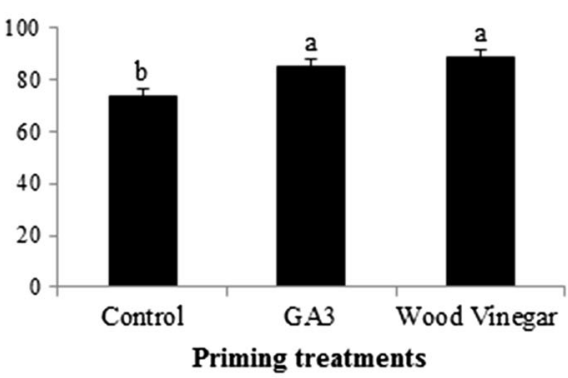

e Emergence (plants $\mathbf{m}^{-2}$ )

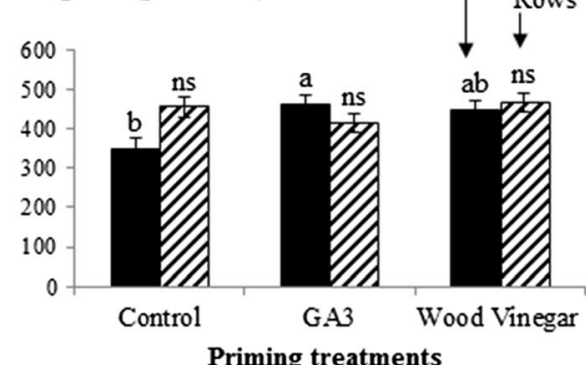

Priming treatments
2014

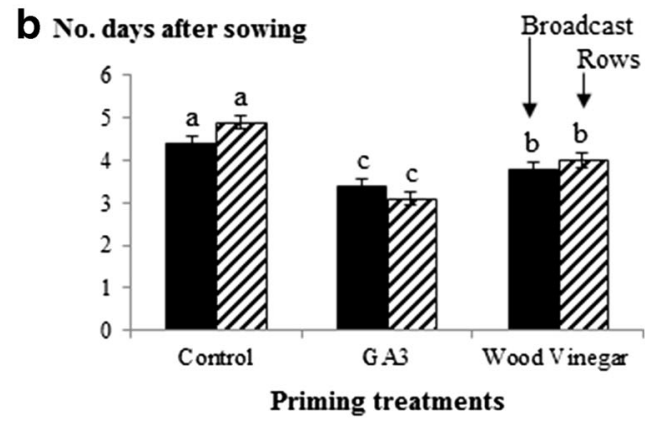

d Germination (\%)

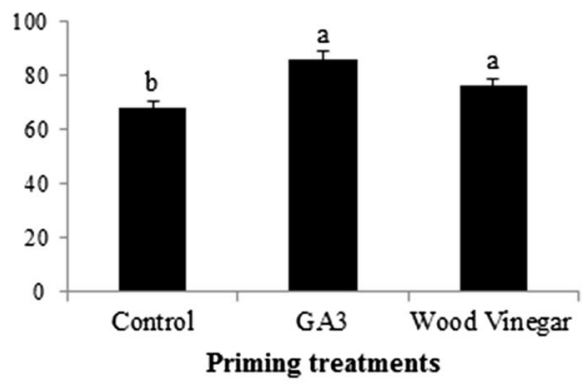

f Emergence (plants $\mathrm{m}^{-2}$ )

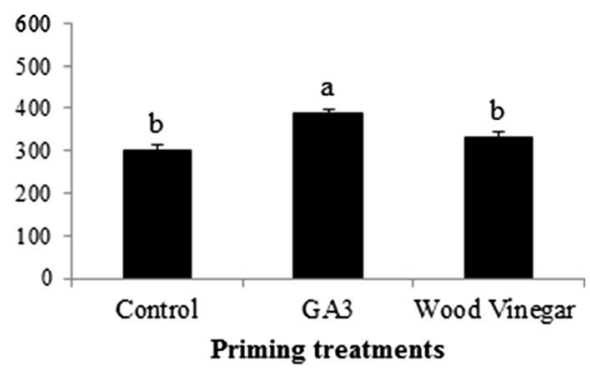


at 20 days after planting, the effect of seed priming was different for cultivar KDML 105 than for RD6 (significant $\mathrm{CxS}$ interaction) in 2013 and was different for broadcast planting than for row planting (significant PxS interaction) in 2014. Weed biomass was significantly greater in the untreated plots for RD6 in 2013 and for row planting in 2014, but was not significantly different from plots planted with primed seed for cultivar KDML 105 (2013) or broadcast planting (2014). Our data showed that KDML 105 had greater leaf area index than RD6 rice cultivar (data not shown). Greater leaf area can outcompete weeds for sun light. Similarly, broadcast planted plots had a more even distribution of plants over the soils surface preventing weed germination. However, based on the published literature, we expected consistent weed suppression in plots planted with primed seed (Boyd et al. 2009). Only weed biomass at 140 DAS in 2013 was significantly greater than those planted with wood vinegar-primed seed, but not different than plots planted with $\mathrm{GA}_{3}$-primed seed (Fig. 4). The three-way interaction among $\mathrm{C}, \mathrm{P}$, and $\mathrm{S}$ at 140 days after planting was significant in 2014.

The inconsistent effects of seed priming on weed biomass suppression were unexpected. A vigorous crop stand early should have increased crop-weed competition for water, nutrients and light (Rehman et al. 2013) and negatively affected weed biomass. The final germination percentage was greater in plots planted with $\mathrm{GA}_{3}$ and wood vinegar-primed seeds (Fig. 3). Primed seed also emerged faster as shown by a shorter germination time (number of days after sowing) (Fig. 3). The final emergence measured as plants $\mathrm{m}^{-2}$ also was greater in plots planted with primed seed (Fig. 3), even though the advantage of seed priming was not as consistent. However, the lower weed competition in 2013 could partially explain the greater no. of tillers plant ${ }^{-1}$ and yield (ton ha ${ }^{-1}$ ) observed in 2013 (Fig. 3). Weed competition is a serious problem in Dry-DSR rice. Our research did not show a clear advantage of seed priming and dense planting, such as broadcast planting, over weed biomass suppression. However, on a year with greater soil moisture from flowering to harvest (2013), weed

\section{Weed biomass $\left(\mathrm{g} \mathrm{m}^{-2}\right)$}

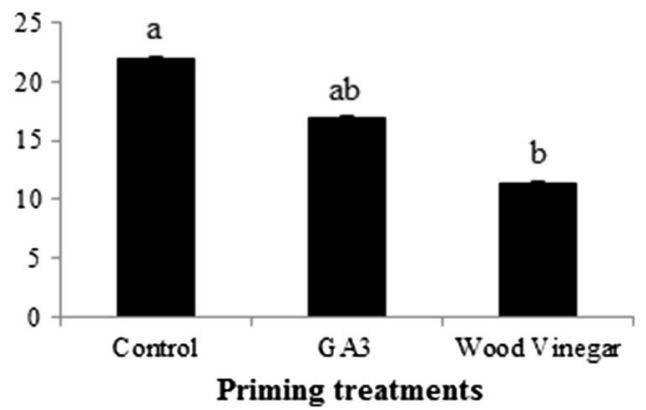

Fig. 4 Weed biomass in $\mathrm{g} \mathrm{m}^{-2}$ at 140 DAS for farmer's field plots planted with primed seed in 2013. Priming treatments were hydropriming with $\mathrm{GA}_{3}$, hydro-priming with wood vinegar, and untreated control suppression was significantly better in plots planted with primed seed.

\subsection{Yield and yield components}

The effect of priming treatments on many yield-related agronomic performance characteristics was inconsistent (data not shown). The total number of seed panicle ${ }^{-1}$, seed weight panicle $^{-1}, 1000$ seed weight, average percentage of fertile and non-fertile panicles ${ }^{-1}$, and HI were significant only 1 year, but not always in the same year. The two-way interactions between $\mathrm{C}$ and $\mathrm{S}$ and $\mathrm{P}$ and $\mathrm{S}$ were also significant for most of these agronomic performance characteristics.

Seed priming had a significantly positive yield effect in 2013 but not in 2014. Only plant stand at harvest was significantly denser in plots planted with wood vinegar-primed seed in 2014 (data not shown). The average number of tillers plant $^{-1}$ was significantly greater both years, but only translated into higher yields in 2013 (Fig. 5). These results contradicted those from other studies where seed priming enhanced not only early agronomic performance, but also yield (Farooq et al. 2005; Farooq et al. 2006). These authors found that seed priming improved early agronomic performance, grain yield, and $\mathrm{HI}$ as compared to untreated seed. However, our study measured rice performance under dryland Dry-DSR while Farooq et al. $(2005,2006)$ measured performance under irrigated Wet-DSR. Under irrigation, the primed seeds yielded better than the untreated control. The authors attributed the yield differences, in part, to a significant increase in the number of tillers plant ${ }^{-1}$. In our experiments, seed priming also increased the number of tillers plant ${ }^{-1}$ both in 2013 and 2014, and grain yield in 2013. In 2013, plants suffered water deficit earlier in the growing season (42 to 60 DAS) (Fig. 2) but had a good supply of soil moisture from 70 DAS to harvest. During this period, plants were at the critical stages of flowering and seed development. The soil moisture was erratic in 2014 under dryland conditions, which could account for the differences in grain yield. Other researchers have established that, in the absence of plant density differences, early emergence and growth in the field did not always result in higher yields (TeKrony and Egli 1991).

\section{Conclusions}

Seed priming before planting increased speed of germination and final germination percentage under laboratory and field conditions. Dryland rice grown from seed primed with wood vinegar and $\mathrm{GA}_{3}$ had similar agronomic performance characteristics. Seed priming treatments increased yield in 2013, when soil moisture availability was more favorable and rainfall was more consistent. Seed priming may be used in Dry-DSR to increase yield, but this treatment has a positive effect only under optimum soil 
Fig. 5 Number of tillers plant ${ }^{-1}$ in 2013 (a) and 2014 (b) and grain yield in ton $\mathrm{ha}^{-1}$ in 2013 (c) for farmer's field plots planted with primed seed. Priming treatments were hydro-priming with $\mathrm{GA}_{3}$, hydro-priming with wood vinegar, and untreated control
2013

a No. tiller plant ${ }^{-1}$
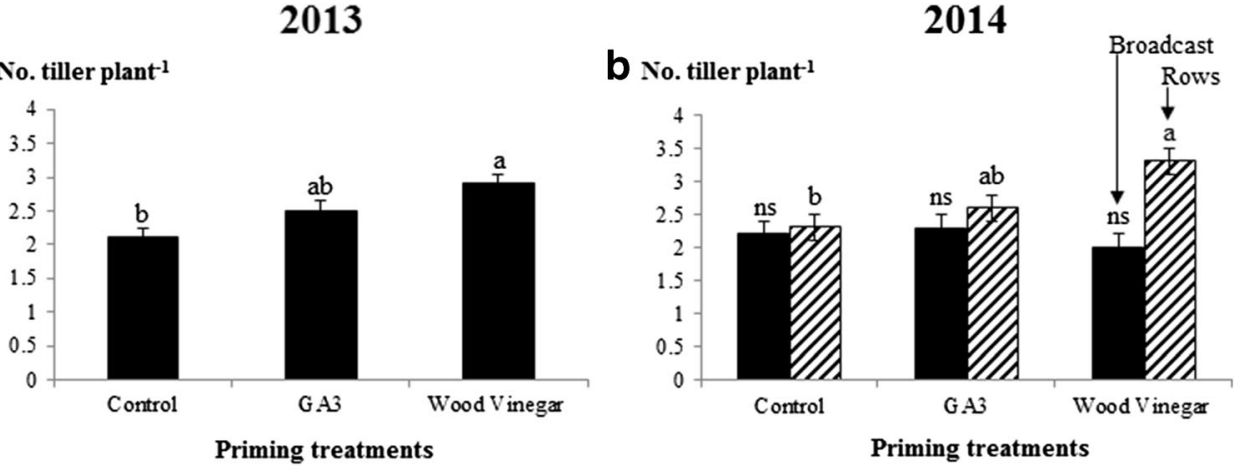

C Grain Yield (ton ha-1)

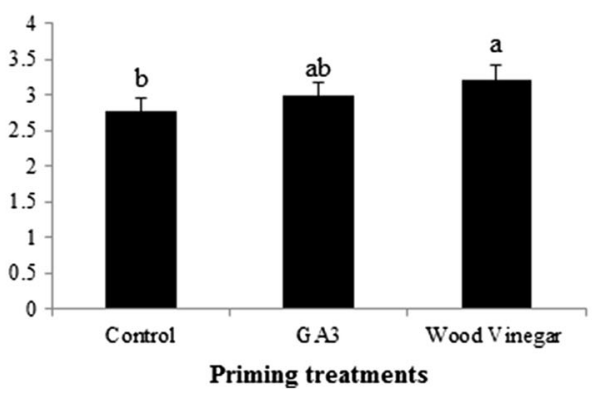

moisture during flowering and seed set. Because wood vinegar is a sustainable and potentially yield enhancing alternative to $\mathrm{GA}_{3}$, we recommend that farmers prime rice seed with wood vinegar, a by-product of charcoal burning that is readily available in dryland rice production areas of Asia.

Funding information This research was supported by the Royal Golden Jubilee Ph.D. Program under jointed funding of The Thailand Research Fund (TRF) and Khon Kaen University and was provided financial support for manuscript preparation activities by the Thailand Research Fund (TRF) Project code: IRG5780003, Khon Kaen University (KKU) and the Faculty of Agriculture, Khon Kaen University.

\section{References}

Anwar MP, Juraimi AS, Puteh A, Selamat A, Man A, Hakim MA (2011) Seeding method and rate influence on weed suppression in aerobic rice. Afr J Biotechnol 10:15259-15271. https://doi.org/10.5897/ AJB11.060

Ashraf M, Foolad MR (2005) Pre-sowing seed treatment-a shotgun approach to improve germination, plant growth, and crop yield under saline and non-saline conditions. Adv Agron 88:223-271. https:// doi.org/10.1016/S00652113(05)88006-X

Basra SMA, Farooq M, Tabassum R (2005) Physiological and biochemical aspects of seed vigor enhancement treatments in fine rice (Oryza sativa L.) Seed Sci Technol 33:623-628

Berahim Z, Panhwar QA, Ismail MR et al (2014) Rice yield improvement by foliar application of phytohormone. J Food Agric \& Environ 12: 399-404

Boyd NS, Brennan EB, Smith RF, Yokota R (2009) Effect of seeding rate and planting arrangement on rye cover crop and weed growth. Agron J 101:47-51. https://doi.org/10.2134/agronj2008.0059

Chalermsan Y, Peerapan S (2009) Wood vinegar: by-product from rural charcoal kiln and its role in plant protection. As J Food Ag-Ind, Special Issue, pp 189-195
Cha-um S, Yooyongwech S, Supaibulwatana K (2010) Water deficit stress in the reproductive stage of four indica rice (Oryza sativa L.) genotypes. Pak J Bot 42:3387-3398

Du LV, Tuong TP (2002) Enhancing the performance of dry-seeded rice: effects of seed priming, seedling rate, and time of seedling. In: Pandey S, Mortimer M, Wade L, Tuong TP, Lopes K, Hardy B (eds) Direct seeding: research strategies and opportunities. International Rice Research Institute, Manila, pp 241-256

Ellis RH, Hong TD, Roberts EH (1985) Handbook of seed technology for gene banks I. Principles and methodology. International Board for Plant Genetic Resources, Rome

Farooq M, Basra SMA, Hafeez K, Ahmad N (2005) Thermal hardening: a new seed vigor enhancement tool in rice. J Integr Plant Biol 47: 187-193. https://doi.org/10.1111/j.1744-7909.2005.00031.x

Farooq M, Basra SMA, Wahid A (2006) Priming of field-sown rice seed enhances germination, seedling establishment, allometry and yield. Plant Growth Regul 49:285-294. https://doi.org/10.1007/s10725006-9138-y

Farooq M, Basra SMA, Asad SA (2008) Comparison of conventional puddling and dry tillage in rice-wheat system. Paddy Water Environ 6:397-404. https://doi.org/10.1007/s10333-008-0138-6

Flematti GR, Ghisalberti EL, Dixon KW, Trengove RD (2004) A compound from smoke that promotes seed germination. Sci 305:977. https://doi.org/10.1126/science.1099944

Ghansham P, Surjit S (2008) Effect of seed rate, spacing and herbicide use on weed management in direct seeded upland rice (Oryza sativa L.) Indian J Weed Sci 40:11-15

Giri GS, Schilinger WF (2003) Seed priming winter wheat for germination, emergence, and yield. Crop Sci 43:2135-2141. https://doi.org/ 10.2135/cropsci2003.2135

Guan B, Cao D, JB Y (2014) Eco-physiological responses of seed germination of sweet sorghum to seed priming. Chin J Ecol 33:982988

Hedden P, Phillips AL (2000) Gibberellin metabolism: new insights revealed by the genes. Trends Plant Sci 5:523-530. https://doi.org/10. 1016/S1360-1385(00)01790-8 
International Seed Testing Associate [ISTA] (2004) International rules for seed testing. Secretariat, Switzerland

Jacobson JV, Gubler F, Chandler PM (1995) Gibberellin action in germinated cereal grains. In: Davies PJ (ed) Plant hormones: physiological, biochemistry and molecular biology. Kluwer, pp 246-271

Kumar V, Ladha JK (2011) Direct-seeding of rice: recent developments and future research needs. Adv Agron 111:297-413. https://doi.org/ 10.1016/B978-0-12-387689-8.00001-1

McDonald MB (1998) Seed quality assessment. Seed Sci Res 8:265-276. https://doi.org/10.1017/s0960258500004165

Moldenhauer K, Charles EW, Counce P, Hardke J (2013) Rice growth and development. In: Arkansas Rice Production Handbook MP 192. Ed. Hardke, U. of Arkansas Div. of Ag. Coop. Ext. Ser., Little Rock, AK. www.uaex.edu/publications/pdf/mp192/chapter-2.pdf. Accessed 8 May 2017

Pandey S, Velasco L (2002) Economics of direct seeding in Asia: patterns of adoption and research priorities. In: Pandey S, Mortimer M, Wade L, Tuong TP, Lopez K, Hardy B (eds) Direct seeding: research strategies and opportunities. International Rice Research Institute, Los Baños, pp 3-14

Phuong LT, Denich M, Vlek PLG, Balasubramanian V (2005) Suppressing weeds in direct seeded lowland rice: effects of methods and rates of seeding. J Agron Crop Sci 191:185-194. https://doi.org/ 10.1111/j.1439-037X.2005.00151.x

Rao AN, Johnson DE, Sivaprasad B, Ladha JK, Mortimer AM (2007) Weed management in direct-seeded rice. Adv Agron 93:153-255. https://doi.org/10.1016/S0065-2113(06)93004-1
Rehman HU, Basra SMA, Farooq M (2011) Field appraisal of seed priming to improve the growth, yield and quality of direct seeded rice. Turk J Agric For 35:357-365. https://doi.org/10.3906/tar-1004-954

Rehman HU, Basra SMA, Wahid A (2013) Optimizing nitrogen split application time to improve dry matter accumulation and yield in dry direct seeded rice. Int J Agric Biol 15:41-47

Roder W (2001) Slash-and-burn rice systems in the hills of northern Lao PDR. In description, challenges, and opportunities. International Rice Research Institute, Los Banos, Philippines, p 201

Sarkarung S, Somrith B, Chirakorn S (2000) Aromatic rices of Thailand. In: Singh RK, Singh US, Khush GS (eds) Aromatic rices. International Rice Research Institute, Newdelhi, pp 180-183

TeKrony DM, Egli DB (1991) Relationship of seed vigor to crop yield: a review. Crop Sci 31:816-822

Tian Y, Guan B, Zhou D, Yu J, Li G, Lou Y (2014) Responses of seed germination, seedling growth, and seed yield traits to seed pretreatment in Maize (Zea mays L.) Sci World J 2014:1-8. https://doi.org/ $10.1155 / 2014 / 834630$

Walkley A, Black IA (1934) An examination of Degtjareff method for determining soil organic matter and a proposed modification of the chromic acid titration method. Soil Sci 37:29-37

Watanabe H, Hase S, Saigusa M (2007) Effects of the combined application of ethephon and gibberellins on growth of rice (Oryza sativa L.) seedlings. Plant Prod Sci 10:468-472. https://doi.org/10.1626/pps. 10.468

Wititsiri S (2011) Production of wood vinegars from coconut shells and additional materials for control of termite workers, Odontotermes $s p$. and striped mealy bugs, Ferrisia virgata. Songklanakarin. J Sci Technol 33:349-354 